\title{
Cause of Death in Japanese Patients with Amyotrophic Lateral Sclerosis on Tracheostomy-Positive Pressure Ventilation
}

\author{
Yutaka Furukawa ${ }^{\mathrm{a}}$ Kiyonobu Komai ${ }^{\mathrm{a}}$ Chiho Ishida ${ }^{\mathrm{a}}$ Kazuya Takahashi ${ }^{\mathrm{a}}$ Atsuro Tagami ${ }^{\mathrm{b}}$ \\ Yuko Motozaki ${ }^{a}$ Tokuhei Ikeda ${ }^{a}$
}

Departments of a Neurology and ${ }^{\mathrm{b}}$ Internal Medicine, National Hospital Organization lou National Hospital,

Kanazawa, Japan

Dear Sirs,

Amyotrophic lateral sclerosis (ALS) is a neurodegenerative disorder characterized by loss of upper and lower motor neurons, leading to weakness and wasting of the affected muscles [1]. Previous reports have shown that the most common cause of death in patients with ALS is respiratory failure followed by other causes, including cardiac problems (myocardial infarction, arrhythmia), sepsis and malignancies [25]; however, knowledge about the causes of death in patients treated with tracheostomy-positive pressure ventilation (TPPV) is very limited. In this study, we investigated the causes of death of ALS patients on TPPV.

We retrospectively reviewed the medical records of 112 consecutive patients with ALS referred to our hospital between April 2006 and September 2011. Diagnosis of ALS was made according to El Escorial diagnostic criteria [6] and clinically probable or definite patients were evaluated in this study. We identified 51 patients who died in this period and divided them into two groups: 13 patients who had been assisted with TPPV at the time of death and 38 patients who had not ( 9 patients had been assisted with noninvasive positive pressure ventilation, and 29 patients had not received any mechanically assisted ventilation). The causes of death were eval- uated from the medical records and autopsy findings if available. Differences between the two groups were assessed by nonparametric analysis.

The characteristics of the patients are shown in table 1 . There were no significant differences in gender, age at onset and age at death between the two groups; however, disease duration was significantly longer in patients with TPPV than without TPPV (Wilcoxon's test, p < 0.05). The hospitalization period until death was also significantly longer in patients with TPPV (Wilcoxon's test, $\mathrm{p}<0.05)$. All patients with TPPV died in hospital, whereas a few patients without TPPV died at home. Twenty-two patients underwent autopsy and the diagnosis of ALS was confirmed in all patients by pathologic study.

The causes of death in this study are shown in table 2 . The most frequent cause of death in patients with TPPV was respiratory failure (46.2\%), as well as in patients without TPPV (89.6\%). It was previously reported that $81.3 \%$ of ALS patients without TPPV died of respiratory failure [4]. Taken together with a previous report [4] and our study, the frequency of respiratory failure as a cause of death in patients with TPPV seems to be lower than in patients without TPPV. In addition, it is notable that all patients with TPPV developed re- spiratory failure from pneumonia/bronchopneumonia, whereas most patients without TPPV developed respiratory failure from terminal respiratory insufficiency due to respiratory muscle weakness.

Problems other than respiratory failure, especially sepsis, arise as a cause of death in patients with TPPV. In patients with sepsis, two of three patients with urinary tract infection had urinary tract stones and the patients with biliary tract infection had gall bladder stones. It is conceivable that these stones may partly affect urinary or biliary tract infection, leading to sepsis. In addition to the existence of stones, the presence of antibiotic-resistant bacteria should be considered. In patients with TPPV, as the disease duration lengthens, the opportunities for developing infectious disease increase. By repeated use of antibacterial drugs, antibiotic-resistant bacteria may increase and it gradually becomes difficult to control infectious diseases such as pneumonia/bronchopneumonia, and urinary or biliary tract infections. In our study, 8 of 13 patients with TPPV were found to have methicillin-resistant Staphylococcus aureus (MRSA) by sputum or urine culture performed within 3 months before death. It is uncertain whether MRSA directly affected the condition of our patients; however, it is con-

\section{KARGER}

Fax +4161306 1234 E-Mail karger@karger.ch www.karger.com
(C) 2012 S. Karger AG, Basel

$0014-3022 / 12 / 0685-0261 \$ 38.00 / 0$

Accessible online at:

www.karger.com/ene
Yutaka Furukawa, MD, PhD

Department of Neurology, National Hospital Organization Iou National Hospital Ni-73-1, Iwade-machi

Kanazawa 920-0192 (Japan)

Tel. +81 76258 1180, E-Mail furukawa@med.kanazawa-u.ac.jp 
Table 1. Clinical characteristics of the patients according to the respiratory support

\begin{tabular}{|c|c|c|}
\hline & \multicolumn{2}{|c|}{ Respiratory support } \\
\hline & $\begin{array}{l}\text { with TPPV } \\
(\mathrm{n}=13)\end{array}$ & $\begin{array}{l}\text { without TPPV } \\
(\mathrm{n}=38) \\
(\text { NIPPV } \mathrm{n}=9 \text {, } \\
\text { no assistance } \\
\mathrm{n}=29)\end{array}$ \\
\hline Gender, male/female & $10 / 3$ & $21 / 17$ \\
\hline Age at onset, years (mean $\pm S D)$ & $59.7 \pm 13.8$ & $65.4 \pm 10.9$ \\
\hline Range & $39-83$ & $34-83$ \\
\hline Age at death, years (mean $\pm \mathrm{SD})$ & $68.5 \pm 11.9$ & $68.6 \pm 9.6$ \\
\hline Range & $46-87$ & $46-84$ \\
\hline \multicolumn{3}{|c|}{ Disease duration, months* ${ }^{*}$ mean $\left.\pm \mathrm{SD}\right) 103.5 \pm 61.841 .6 \pm 35.4$} \\
\hline Range & $24-246$ & $8-159$ \\
\hline \multicolumn{3}{|l|}{ Site of onset, $\mathrm{n}(\%)$} \\
\hline Bulbar & $5(38.4)$ & $14(36.9)$ \\
\hline Respiratory failure & $2(15.4)$ & 0 \\
\hline Upper extremities & $4(30.8)$ & $17(44.7)$ \\
\hline Lower extremities & $2(15.4)$ & $7(18.4)$ \\
\hline \multicolumn{3}{|l|}{ Nutrition support, n (\%) } \\
\hline Oral intake & 0 & $9(23.7)$ \\
\hline Nasogastric tube & $2(15.4)$ & $3(7.9)$ \\
\hline Gastrostomy & $11(84.6)$ & $25(65.8)$ \\
\hline Intravenous hyperalimentation & 0 & $1(2.6)$ \\
\hline \multicolumn{3}{|l|}{ Place of death, $\mathrm{n}(\%)$} \\
\hline Home & 0 & $4(10.5)$ \\
\hline Hospital & $13(100)$ & $34(89.5)$ \\
\hline Hospitalization period until death & $73.0 \pm 57.8$ & $7.9 \pm 12.7$ \\
\hline month, range ${ }^{*}($ mean $\pm S D)$ & $14.5-230$ & $0.1-67^{* *}$ \\
\hline Autopsied patients, n (\%) & $9(69.2)$ & $13(34.2)$ \\
\hline
\end{tabular}

$\mathrm{TPPV}=$ Tracheostomy-positive pressure ventilation; NIPPV = noninvasive positive pressure ventilation.

${ }^{*} \mathrm{p}<0.05 ;{ }^{*}$ except four patients who died at home.
Table 2. Cause of death of ALS patients according to the respiratory support

\begin{tabular}{|c|c|c|}
\hline & \multicolumn{2}{|c|}{ Respiratory support } \\
\hline & $\begin{array}{l}\text { with TPPV } \\
(\mathrm{n}=13)\end{array}$ & $\begin{array}{l}\text { without TPPV } \\
(\mathrm{n}=38) \text { (NIPPV } \\
\mathrm{n}=9, \text { no assis- } \\
\text { tance } \mathrm{n}=29)\end{array}$ \\
\hline Respiratory failure, n (\%) & $6(46.2)$ & $34(89.6)$ \\
\hline Pneumonia/bronchopneumonia & 6 & 6 \\
\hline Terminal respiratory insufficiency & 0 & 26 \\
\hline Asphyxia & 0 & 2 \\
\hline Sepsis, n (\%) & $4(30.8)$ & $1(2.6)$ \\
\hline Urinary tract infection & 3 & 0 \\
\hline Biliary tract infection & 1 & 0 \\
\hline Unknown infectious origin & 0 & 1 \\
\hline Heart failure, n (\%) & $1(7.7)$ & $1(2.6)$ \\
\hline Ventricular fibrillation & 1 & 0 \\
\hline Congestive heart failure & 0 & 1 \\
\hline Malignancy, n (\%) & $1(7.7)$ & $1(2.6)$ \\
\hline Carcinoma of the oral floor & 1 & 0 \\
\hline Hepatocellular carcinoma & 0 & 1 \\
\hline Intestinal problem, $\mathrm{n}(\%)$ & $1(7.7)$ & $1(2.6)$ \\
\hline Ileus & 1 & 0 \\
\hline Intestinal hemorrhage & 0 & 1 \\
\hline
\end{tabular}

TPPV = Tracheostomy-positive pressure ventilation; NIPPV = noninvasive positive pressure ventilation. ceivable that there is a background for developing antibiotic-resistant bacteria in patients with TPPV, leading to difficult to control infectious diseases. Generally, it should be noted that infectious diseases were the major cause of death in patients with TPPV.

A recent report, based on the nationwide registration system of the Ministry of Health, Labor and Welfare of Japan, showed that $29.3 \%$ of Japanese ALS patients are treated with TPPV [7]. Conversely, it is reported that the frequency of TPPV-assisted ALS patients is $1.5-3.2 \%$ in western countries $[2,8,9]$; therefore, Japa- nese patients are more likely to undergo invasive ventilation. A better understanding of the cause of death of ALS patients on TPPV is required for patients and their caregivers to improve the decision-making process for TPPV induction and palliative care at the end of life.

Our study is limited by its small number of patients at a single center. In addition, not all patients underwent autopsy and the causes of death were based on a clinical diagnosis in some patients. Further larger studies are required for better understanding of the cause of death of ALS patients on TPPV.

\section{Acknowledgement}

The authors thank Ms. F. Nakamoto (Medical Social Worker, Iou National Hospital, Kanazawa, Japan) for data acquisition.

\section{Disclosure Statement}

The authors declare that they have no conflicts of interest. 


\section{References}

1 Nirmalananthan N, Greensmith L: Amyotrophic lateral sclerosis: recent advances and future therapies. Curr Opin Neurol 2005;18: 712-719.

-2 Gil J, Funalot B, Verschueren A, DanelBrunaud V, Camu W, Vandenberghe N, Desnuelle C, Guy N, Camdessanche JP, Cintas P, Carluer L, Pittion S, Nicolas G, Corcia P, Fleury MC, Maugras C, Besson G, Le Masson $\mathrm{G}$, Couratier P: Causes of death amongst French patients with amyotrophic lateral sclerosis: a prospective study. Eur J Neurol 2008; 15:1245-1251.

- 3 Kurian KM, Forbes RB, Colville S, Swingler $\mathrm{RJ}$ : Cause of death and clinical grading criteria in a cohort of amyotrophic lateral sclerosis cases undergoing autopsy from the Scottish Motor Neurone Disease Register. J Neurol Neurosurg Psychiatry 2009;80:8487.
-4 Spataro R, Lo Re M, Piccoli T, Piccoli F, La Bella V: Causes and place of death in Italian patients with amyotrophic lateral sclerosis. Acta Neurol Scand 2010;122:217-223.

5 Yang R, Huang R, Chen D, Song W, Zeng Y, Zhao B, Zhou D, Shang HF: Causes and places of death of patients with amyotrophic lateral sclerosis in south-west China. Amyotroph Lateral Scler 2011;12:206-209.

6 Brooks BR, Miller RG, Swash M, Munsat TL, World Federation of Neurology Research Group on Motor Neuron Diseases: El Escorial revisited: revised criteria for the diagnosis of amyotrophic lateral sclerosis. Amyotroph Lateral Scler Other Motor Neuron Disord 2000;1:293-299.
7 Atsuta N, Watanabe H, Ito M, Tanaka F, Tamakoshi A, Nakano I, Aoki M, Tsuji S, Yuasa T, Takano H, Hayashi H, Kuzuhara S, Sobue G, Research Committee on the Neurodegenerative Diseases of Japan: Age at onset influences on wide-ranged clinical features of sporadic amyotrophic lateral sclerosis. J Neurol Sci 2009;276:163-169.

8 Bradley WG, Anderson F, Bromberg M, Gutmann L, Harati Y, Ross M, Miller RG, ALS CARE Study Group: Current management of ALS: comparison of the ALS CARE Database and the AAN Practice Parameter. American Academy of Neurology. Neurology 2001;57: 500-504.

9 Ritsma BR, Berger MJ, Charland DA, Khoury MA, Phillips JT, Quon MJ, Strong MJ, Schulz VM: NIPPV: prevalence, approach and barriers to use at Canadian ALS centres. Can J Neurol Sci 2010;37:54-60. 